\title{
Potential risk factors for zoonotic disease transmission among Mongolian herder households caring for horses and camels
}

\author{
Alexandra Sack ${ }^{1,2,3^{*}}$ (D), Ulziimaa Daramragchaa ${ }^{1}$, Maitsetseg Chuluunbaatar', Battsetseg Gonchigoo ${ }^{1}$ \\ and Gregory C. Gray 2,3,4
}

\begin{abstract}
Mongolia has more than ten times as many livestock as people. Herders are dependent on their livestock for their livelihood, and seasonal movement is driven by the livestock's grazing needs. The daily, seasonal interactions between Mongolian herders and their livestock put herders at risk for several zoonotic diseases. The goals of this pilot study were to describe potential risk factors for zoonotic disease transmission and note how they differed for herder families between provinces (aimags). As part of a larger study, a household survey was administered to 131 households in Arkhangai, Uvurkhangai, and Umnugobi provinces aimags during 2016 and 2017. The study was limited due to its self-reported survey data and its convenience sample design. We did not capture specific disease data. All households cared for either or both horses (Equus ferus caballus) and Bactrian camels (Camelus bactrianus). All households had a cell phone and access to a power source, primarily solar panels (93.1\%). Families reported spending on average $3.9 \mathrm{~h}$ a day with their horses or camels. As all five of the most prevalent zoonotic pathogens in Mongolia have horses as reservoirs, and three of the five may also reservoir in Bactrian camels, herder families with horses or camels potentially experience daily risks from zoonotic diseases. Our pilot study data demonstrated that zoonotic disease transmission could occur through a number of ways, such as directly from contact with livestock or manure or from contaminated food, milk, or water. Sixty-four percent of herder households reported using dried manure for fuel. Unprocessed river water was often the primary source (52.7\%) of drinking water, which is potentially contaminated with manure-borne pathogens. Fuel and water sources varied by herder household location. A unifying finding was the ubiquity of cellphones in all surveyed herder households, providing a potentially efficient method for public health communication.
\end{abstract}

Keywords: Mongolia, Household survey, Zoonoses, Bactrian camels, Horses

\section{Introduction}

Livestock are central to the lifestyle and livelihood of many families in Mongolia. Herding comprises almost 90\% of all agriculture in Mongolia and involves an estimated 213,400 households. In 2014, there were 56 million livestock in Mongolia, including over three million horses and almost 400,000 camels (Eldevochir 2016). Horses (Equus ferus caballus) and Bactrian camels (Camelus bactrianus) are used as transportation and as a food

\footnotetext{
* Correspondence: aes105@duke.edu

${ }^{1}$ Institute of Veterinary Medicine, Ulaanbaatar, Mongolia

${ }^{2}$ Division of Infectious Diseases, School of Medicine, Duke University, Box

90519, Durham, NC 27710, USA

Full list of author information is available at the end of the article
}

source for milk and meat, with camels also producing wool (Bat-Oyun et al. 2015, Zhen et al. 2010, Faye 2015). However, as people are greatly dependent on their livestock for survival through this pastoralist lifestyle, it can expose a herder and his/her household to several zoonotic health risks.

Zoonotic diseases are diseases that are transmitted between animals and people. According to the National Center for Zoonotic Diseases (NCZD), five of the most prevalent zoonotic diseases in Mongolia include tickborne rickettsiosis, anthrax, rabies, tick-borne encephalitis, and brucellosis. Worldwide, horses have been found to be carriers for all five of these diseases (Rushton et al. 2013, Turner et al. 1999, Merini et al. 2010, Moraes Filho 
et al. 2009, Santos et al. 2016, Tahamtan et al. 2010) and have been found specifically to carry rabies, anthrax, and brucellosis in Mongolia (Odontsetseg et al. 2009, Zolzaya et al. 2014, Odontsetseg et al. 2007). A similar study rating the risks of zoonotic disease in Mongolia to humans and livestock found brucellosis, rabies, and anthrax to be three of the top four most important diseases, with the fourth being echinococcosis (McFadden et al. 2016). Both horses and camels can be infected by Echinococcus spp. (Ito and Budke 2015, Acosta-Jamett et al. 2010).

Bactrian camels are susceptible to anthrax, rabies, brucellosis, and echinococcosis in Mongolia (Ito and Budke 2015, Odontsetseg et al. 2009, Odontsetseg et al. 2007, Zolzaya et al. 2014). Furthermore, camels were the second most likely livestock after cattle to test positive for rabies in a summary of rabies cases in Mongolia from 1970 to 2005. During the same period, there were 34 human cases of rabies demonstrating a zoonotic exposure risk (Odontsetseg et al. 2009). The health of Mongolian herders is also influenced by their mobility, including seasonal migration, (Mocellin and Foggin 2008) often driven by livestock as herders seek better pastures or water (Miao et al. 2016). Associations have been recorded between livestock deaths and human deaths during $d z u d s$, which are severe, winter weather events (Otani et al. 2016).

The semi-nomadic households of rural Mongolia are potentially at risk for many zoonotic diseases, but sparse research has examined the household characteristics which increase the threats of exposure. A 2006 survey conducted in Tov aimag (province) studied herding household characteristics (Zhen et al. 2010). In the current study, we sought to examine household risk factors among Mongolian herding households with camels and horses and the potential role these characteristics have in the transmission of zoonotic diseases. We also illustrated areas for interventions to promote safer human-animal contact in this unique setting.

\section{Study area}

Mongolia is a landlocked country between the Russian Federation and the People's Republic of China (Sharma and Davaakhuu 2015). There are high annual and daily temperature fluctuations from $-53{ }^{\circ} \mathrm{C}$ in January to $42{ }^{\circ} \mathrm{C}$ in July, countrywide (Marin 2010). Of the total land area, approximately $75 \%$ of all land is used as livestock pasture, and approximately $8 \%$ is forest. Countrywide, there is a population density of less than two people per square $\mathrm{km}$, which is one of the lowest in the world (United Nations Data 2017).

In 2016, Mongolia's total population was approximately $3,006,000$ of which approximately $1,370,000$ lived in the capital city of Ulaanbaatar. An estimated $72 \%$ of Mongolia's population live in urban areas while the rural areas remain impoverished. In 2012, it was estimated that $35.5 \%$ of the rural population lived in poverty compared to $23.2 \%$ of the urban population (Sharma and Davaakhuu 2015). As of 2015, agriculture was the largest sector of the economy at $27.8 \%$ of the gross domestic product (Sharma and Davaakhuu 2015).

The pastoralist economy relies on five main domestic animal species: sheep, goats, horses, cattle, and camels. Patterns of migration for the semi-nomadic herders are seasonal and based on pasture availability for livestock (Marin 2010). Pasture growth is generally from mid-May to mid-August, and frost can start as early as the end of August. Water in the steppe and Gobi regions is often the limiting factor with some pasture only being usable in winter when there is snow. Mountain steppe areas usually have plenty of surface water (Suttie 2005).

This household survey was conducted in three of Mongolia's 21 aimags which were selected because of their large number of horses and camels. Arkhangai and Uvurkhangai aimags are located in central Mongolia, and Umnugobi aimag is located in the south, sharing a border with China (Figure 1).

Arkhangai has a human population of 93,000 people and an area of $55,300 \mathrm{~km}^{2}$ (Mongolian National Chamber of Commerce and Industry 2017). There are estimated $4,047,000$ total livestock in the aimag, of which 324,100 are horses and 1100 camels (National Statistics Office 2015). Arkhangai is in the Khangai-Khosvol region and is primarily mountainous with scattered forests (Figure 2). For livestock, there is mixed grazing with yaks replacing cattle at higher altitudes (Suttie 2005).

Uvurkhangai has a human population of more than 112,000 people and an area of $63,500 \mathrm{~km}^{2}$ (Mongolian National Chamber of Commerce and Industry 2017). There are an estimated 4,511,000 total livestock in the aimag, of which 280,200 are horses and 23,100 are camels (National Statistics Office 2015). Uvurkhangai is partly in the central and eastern steppe region (Figure 2), and part of the southern portion of the aimag is in the

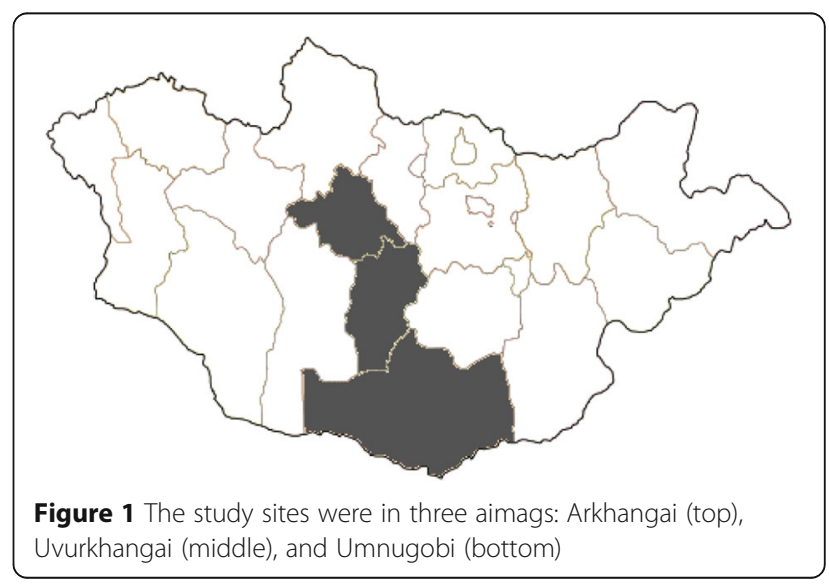



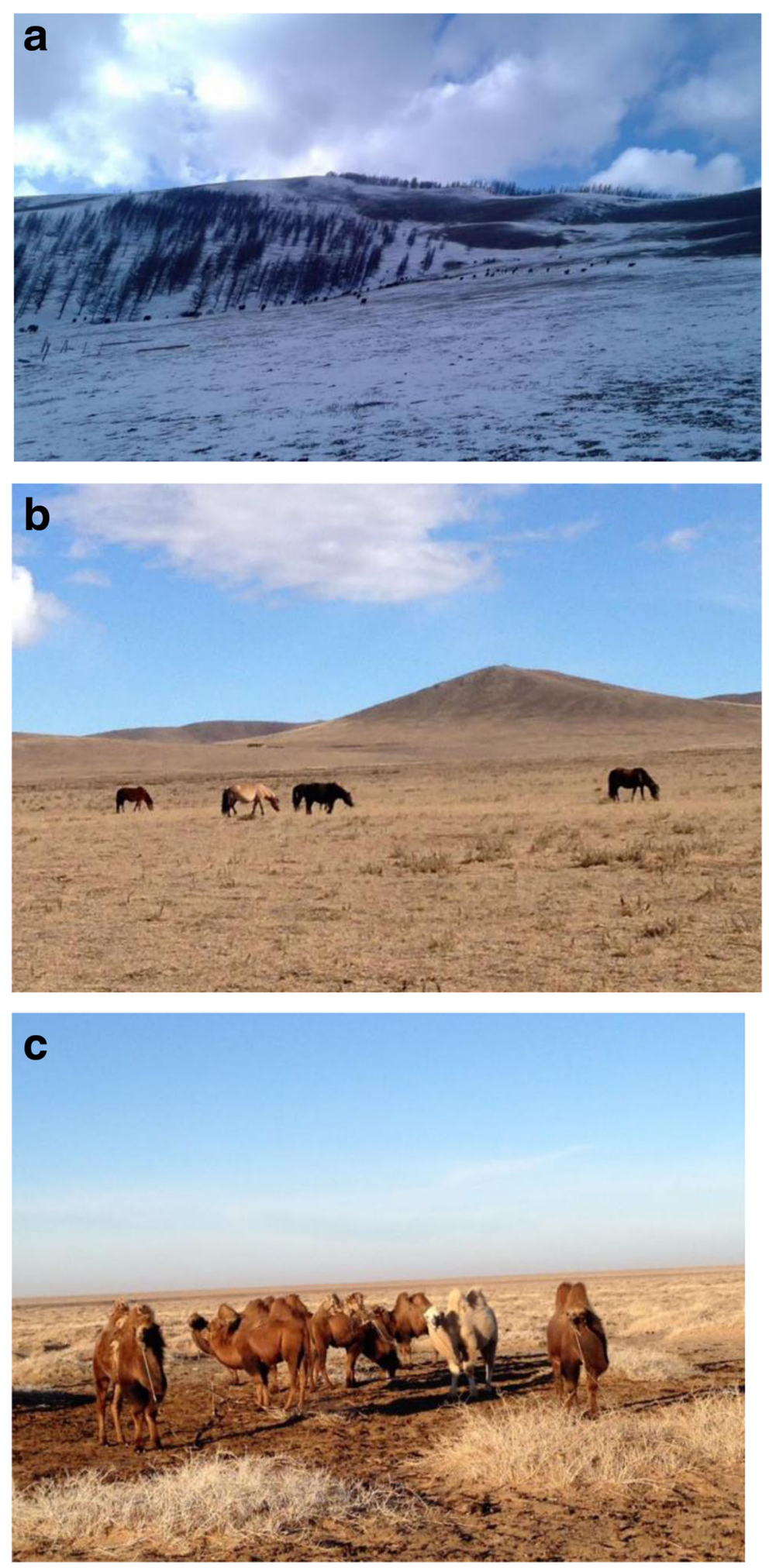

Figure 2 Photographs of the representative topography from each aimag. The three study sites represent different regions. Arkhangai (a) is primarily mountainous with scattered forests, Uvurkhangai (b) is primarily steppe, and Umnugobi (c) consists of desert and desert steppe 
Gobi region. The central and eastern steppe region is characterized by broad, treeless plains, and all five main livestock are common (Suttie 2005).

Umnugobi has a human population of 46,300 and an area of $165,000 \mathrm{~km}^{2}$ (Mongolian National Chamber of Commerce and Industry 2017). There are an estimated $2,055,800$ total livestock in the aimag, of which 74,200 are horses and 118,600 are camels (National Statistics Office 2015). Umnogobi is in the Gobi region, which is desert steppe and desert (Figure 2). The majority of livestock are camels, horses, cattle, and goats (Suttie 2005). In the Gobi region, precipitation can be as low as $50 \mathrm{~mm} /$ year (Marin 2010).

\section{Methods}

\section{Surveys}

Between February and March 2017, 131 Mongolian herding households were surveyed in a pilot study for zoonotic disease transmission risk factors. This pilot study was part of a larger cross-sectional study investigating the disease burden of equine influenza in Mongolia. Participating households were from Arkhangai, Uvurkhangai, and Umnugobi aimags (Figure 1). In each aimag, four smaller land units called soums (Figure 3) were chosen according to the livestock density records of the soum's agricultural administration and the availability of local veterinarian(s) for assistance. Within each soum, a convenience sampling strategy was used to select households that owned horses or camels according to the local veterinarian.

Surveys were developed in English and translated into the Mongolian language by native Mongolian researchers (Additional file 1). For survey participation, the household had either horses or camels near the ger (portable felt home; yurt) at the time of the site visit, as required by the larger study. Surveys were administered verbally to the self-identified head of the household and recorded by a trained Mongolian field staff member. Responses were translated into English for analysis.

\section{Statistical analysis}

All data were analysed using Microsoft Excel 2016 or STATA 15.0 (StataCorp LLC, 2017). Descriptive statistics were run to characterize the ages of household heads, distance and times moved by the household each year, and median number of horses, camels, and dogs per household. Chi-square or Fisher's exact tests were used to evaluate categorical data such as the effect of aimag location on the head of the household's smoking habits, education level, and the household's drinking water and heating fuel source, as well as the effect of education on smoking. A one-way ANOVA with a Bonferroni correction was used to compare continuous data such as the number of times moved and distance moved by each nomadic household throughout the year. These variables had an approximately normal distribution. The number of horses per aimag was not normally distributed so a Kruskal-Wallis $H$ test was conducted to determine if the number of horses varied by aimag. For all tests, the null hypothesis was that there were no differences between aimags. A $p$ value $\leq 0.05$ was considered statistically significant.

\section{Results}

Head of household demographics: Age, income, education, and tobacco use

Males made up the majority of the heads of participating households ( $n=130 ; 99.2 \%)$, and all heads of the household $(n=131)$ were self-described Khalkh ethnicity. The age of the head of the household ranged from 16 to 71 years old with a mean age of 41 for all aimags (Table 1).

Only 14 heads of the household reported their monthly income, averaging 583,000 MNT (\$242.46) a month. Two heads of the households in Umnugobi reported income from activities outside of herding (Table 1). All households reported access to a power source. The majority of participants used solar power $(n=122 ; 93.1 \%)$. This was consistent across all three aimags (Table 2). All surveyed households reported owning a cell phone, but some indicated that it did not currently work.

The highest education level of the head of household was most often 8 th grade $(n=81 ; 61.8 \%)$. Uvurkhangai had more heads of household with the $>8$ years of education with $32.7 \%(n=16)$ having at least a 10th grade education and $10.2 \%(n=5)$ having some post-secondary education. Heads of the household in Uvurkhangai were 3.6 times more likely to have at least a 10th grade education than the other two aimags ( $\mathrm{OR}=1.6-8.1$; Table 1 ).

Tobacco use among the heads of the household varied by aimag but overall, $42.7 \%(n=56)$ of heads of households reported smoking (Table 2). The average age to start smoking was 22 . More than half $(50.9 \%)$ of the heads of households who smoked used both cigarettes and loose tobacco $(n=28)$. Only Umnugobi $(83.3 \%)$ used cigarettes more than using both types. Heads of the household in Uvurkhangai were 2.6 times more likely to use tobacco than the other two aimags ( $\mathrm{OR}=1.2-5.3)$. There was no significant effect of head of household education on tobacco use $(p=0.64)$.

\section{Household demographics: Livestock, movement, fuel, and water source}

Of the participating households, 106 cared for horses only, 11 for camels only, and an additional 14 had both horses and camels. The median number of horses cared 
a

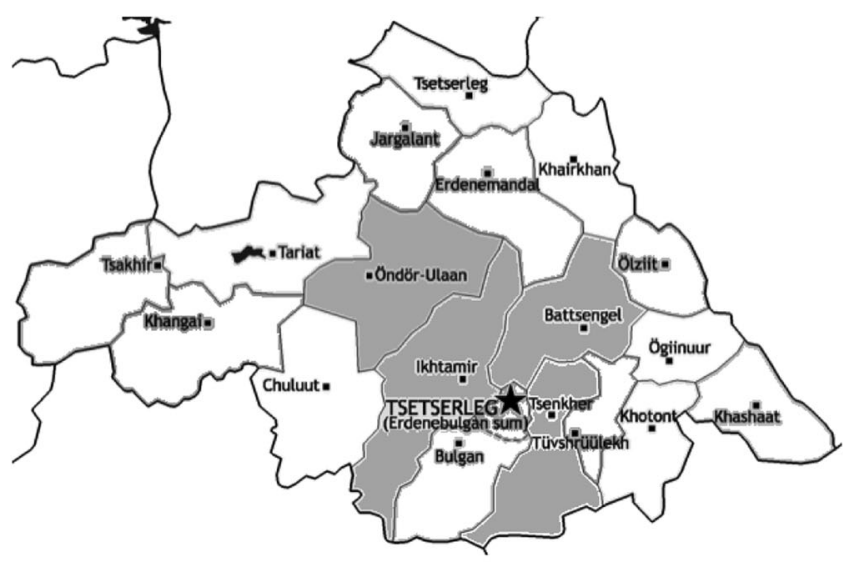

b
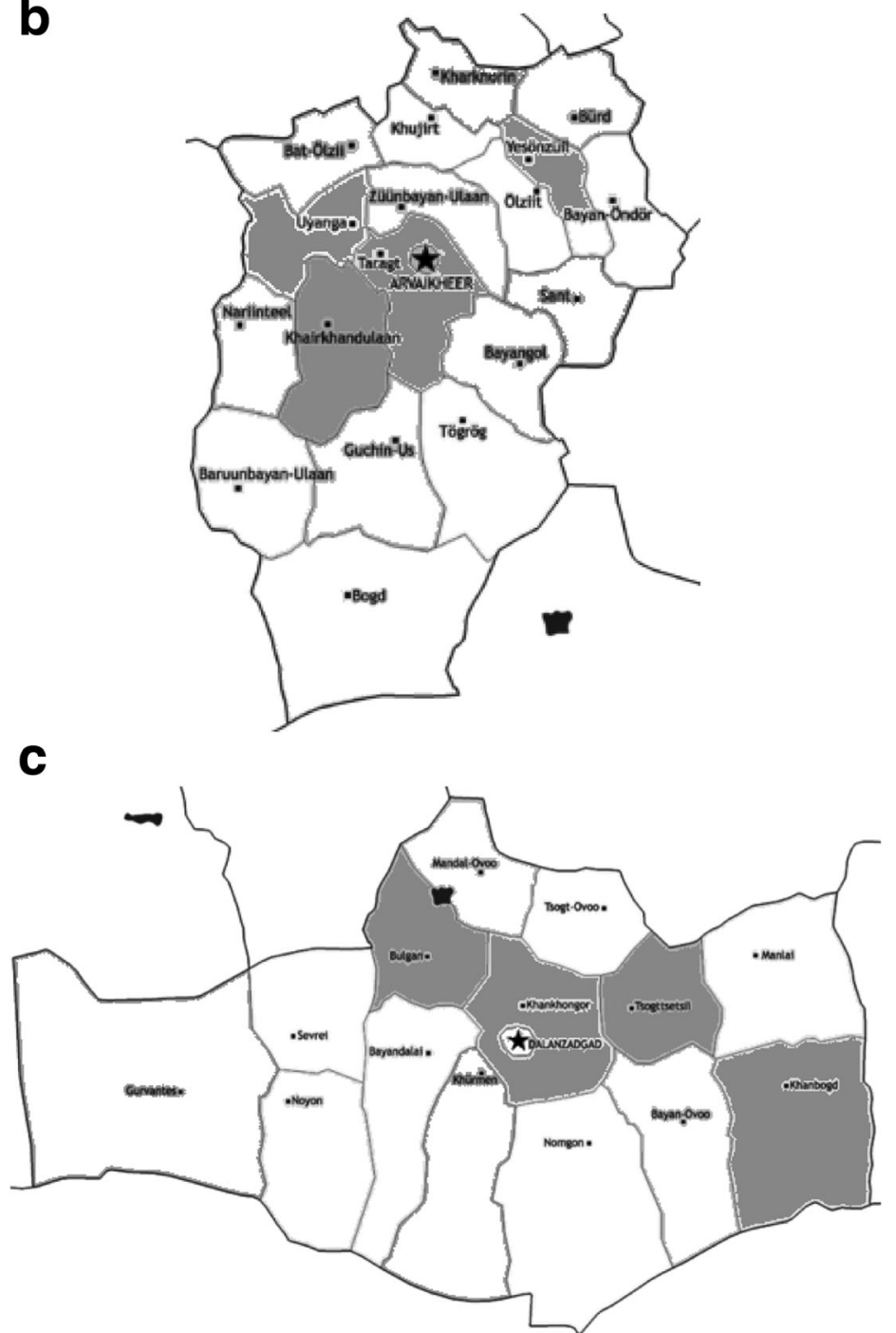

Figure 3 Location of study sites in each aimag. Four soums were surveyed in each aimag: Arkhangai (a), Uvurkhangai (b), and Umnugobi (c)

for by a household was 40 . However, horses per household ranged between 5 and 400 and 10 and 520 for camels. Three households (2.5\%) had more than 200 horses. There was a significant difference in number of horses owned by aimag $(p=0.004)$. Camels were only present in surveyed households of Umnugobi aimag. 
Table 1 Descriptive statistics for the participating survey head of households $(n=131)$

\begin{tabular}{|c|c|c|c|c|c|}
\hline & & Arkhangai & Uvurkhangai & Umnugobi & Total \\
\hline \multirow[t]{2}{*}{ Sex } & Male (\%) & $52(100)$ & $48(98.0)$ & $30(100)$ & $130(99.2)$ \\
\hline & Female (\%) & $0(0.0)$ & $1(2.0)$ & $0(0.0)$ & $1(0.8)$ \\
\hline Ethnicity & Khalkh (\%) & $52(100)$ & $49(100)$ & $30(100)$ & $131(100)$ \\
\hline Age & Average & 42 & 37 & 44 & 41 \\
\hline \multirow[t]{2}{*}{ Income } & Reported income (\%) & $6(11.5)$ & $8(16.3)$ & $0(0.0)$ & $14(10.7)$ \\
\hline & Average (MNT) & 667,000 & 511,000 & NA & 583,000 \\
\hline \multirow[t]{2}{*}{ Income source } & Herding (\%) & $52(100)$ & $49(100)$ & $28(93.3)$ & $129(98.5)$ \\
\hline & Other (\%) & $0(0.0)$ & $0(0.0)$ & $2(6.7)$ & $2(1.5)$ \\
\hline \multirow[t]{4}{*}{ Education } & Up to 4 th grade (\%) & $4(7.7)$ & $7(14.3)$ & $4(13.3)$ & $15(11.5)$ \\
\hline & Up to 8th grade (\%) & $40(76.9)$ & $21(42.9)$ & $20(66.7)$ & $81(61.8)$ \\
\hline & Up to 10 th grade $(\%)$ & $6(11.5)$ & $16(32.7)$ & $5(16.7)$ & $27(20.6)$ \\
\hline & Some post-secondary (\%) & $2(3.8)$ & $5(10.2)$ & $1(3.3)$ & $8(6.1)$ \\
\hline \multirow[t]{2}{*}{ Tobacco used } & Yes (\%) & $21(40.4)$ & $28(57.1)$ & $7(23.3)$ & $56(42.7)$ \\
\hline & No (\%) & $31(59.6)$ & $21(42.9)$ & $23(76.7)$ & $75(57.3)$ \\
\hline \multirow[t]{3}{*}{ Type of tobacco } & Cigarettes (\%) & $7(33.3)$ & $5(17.9)$ & $5(83.3)$ & $17(30.9)$ \\
\hline & Loose tobacco (\%) & $1(4.7)$ & $9(32.1)$ & $0(0.0)$ & $10(18.2)$ \\
\hline & Both types (\%) & $13(61.9)$ & $(50.0)$ & $1(16.7)$ & $28(50.9)$ \\
\hline
\end{tabular}

Table 2 Descriptive statistics for the participating survey households ( $n=131$ )

\begin{tabular}{|c|c|c|c|c|c|}
\hline & & Arkhangai & Uvurkhangai & Umnugobi & Total \\
\hline \multirow[t]{3}{*}{ Households with livestock } & Camels (\%) & $0(0.0)$ & $0(0.0)$ & $25(83.3)$ & $25(19.1)$ \\
\hline & Horses (\%) & $52(100)$ & $49(100)$ & $19(63.3)$ & $120(91.6)$ \\
\hline & Dogs (\%) & $51(98.1)$ & $45(91.8)$ & $24(80.0)$ & $120(91.6)$ \\
\hline \multirow[t]{3}{*}{ Median number of livestock } & Camels & 0 & 0 & 70 & 70 \\
\hline & Horses & 32.5 & 45 & 43 & 40 \\
\hline & Dogs & 1 & 1 & 1 & 1 \\
\hline Time spent with horses or camels & Mean (hours a day) & 3.6 & 3.2 & 3.3 & 3.4 \\
\hline Times moved & Mean & 3.6 & 3.8 & 4.6 & 3.9 \\
\hline Distance moved & Mean (km) & 15.9 & 22.6 & 33.6 & 22.3 \\
\hline \multirow[t]{4}{*}{ Fuel source $^{a}$} & Wood (\%) & $51(98.1)$ & $20(40.8)$ & $17(56.7)$ & $90(68.7)$ \\
\hline & Dried manure (\%) & $22(42.3)$ & $33(67.3)$ & $29(96.7)$ & $84(64.1)$ \\
\hline & Coal (\%) & $0(0.0)$ & $26(53.1)$ & $16(53.3)$ & $42(32.1)$ \\
\hline & Electricity (\%) & $1(1.9)$ & $1(2.0)$ & $0(0.0)$ & $2(1.5)$ \\
\hline \multirow[t]{4}{*}{ Water source ${ }^{b}$} & River (\%) & $38(73.1)$ & $30(61.2)$ & $1(3.3)$ & $69(52.7)$ \\
\hline & Electric well (\%) & $14(26.9)$ & $16(32.7)$ & $21(70.0)$ & $51(38.9)$ \\
\hline & Spring (\%) & $15(28.8)$ & $12(24.5)$ & $1(3.3)$ & $28(21.4)$ \\
\hline & Hand well (\%) & $2(3.8)$ & $3(6.1)$ & $8(26.7)$ & $13(9.9)$ \\
\hline \multirow[t]{3}{*}{ Power source } & Solar power (\%) & $49(94.2)$ & $45(91.8)$ & $28(93.3)$ & $122(93.1)$ \\
\hline & Power generator (\%) & $3(5.8)$ & $0(0.0)$ & $2(6.7)$ & $5(3.8)$ \\
\hline & Electric grid (\%) & $0(0.0)$ & $4(8.2)$ & $0(0.0)$ & $4(3.1)$ \\
\hline
\end{tabular}


The median number of camels per household was 70 . In Umnugobi, 44\% of camel-owning households (11) had between 51 and 100 camels. Two households (8\%) had more than 200 camels. Participants from all aimags reported an average of 3-4 h spent with their horses or camels each day. Most families $(120 ; 91.6 \%)$ had at least one dog, and the median number of dogs was one (Table 2).

The herding households of this study moved frequently throughout the year for water and food for their livestock. Of the 131 households, only 11 did not move during the year (8.3\%). Both Arkhangai and Uvurkhangai households moved on average four times a year, while Umnugobi households moved on average five times a year (Table 2). In Umnugobi aimag, four households $(13.3 \%)$ reported that they did not move, while two households (6.7\%) reported ten moves throughout the year. The mean distance moved each time by the survey households was $22 \mathrm{~km}$. The farthest moved by any family was $110 \mathrm{~km}$ in Umnugobi. There was a statistically significant difference between distance moved by the households according to their aimag $(p=0.005)$. Households in Umnugobi moved significantly further than those in Arkhangai $(p=0.003)$.

Sources for heating fuel and household drinking water were recorded for each family (Table 2). The most common heating fuel was wood, including zag. Zag is specifically a wood from the saxaul tree (Haloxylon ammodendron) in the Gobi region and was used by three households in Umnugobi. In Arkhangai aimag, most households burned wood for heat $(n=51 ; 98.1 \%)$ while in Uvurkhangai, most households used dried manure $(n=33 ; 67.3 \%)$, followed by coal $(n=26 ; 53.1 \%)$. In Umnugobi, almost all surveyed households used dried manure $(n=29 ; 96.7 \%)$. Only two households (1.5\%) used electricity to heat (Table 2). Fuel source was significantly different between aimags $(p<0.001)$. Households in Umnugobi were 24.3 times more likely to burn dried manure for heat than the other two aimags $(\mathrm{OR}=3.2-185.0)$. All study participants reported cooking inside their home or ger.

The source for household drinking water was most commonly a river at $52.7 \%$ (69) but varied significantly by aimag $(p<0.001)$. River water as the primary drinking water source was reported most commonly in Arkhangai with $73.1 \%(n=38)$ and Uvurkhangai with $61.2 \%(n=30)$ of households. In Umnugobi, a generator-powered ground well was used as the primary drinking water source in $70.0 \% \quad(n=21)$ of the surveyed households (Table 2). Thirty households that reported using a river as their first drinking water source also reported using either a spring or an electric well as their second water source. Households in Arkhangai were 4.2 times more likely to use a river as their primary water sources than the other two aimags $(\mathrm{OR}=2.0-9.0)$.

\section{Discussion}

Our pilot study results captured various demographic and herder activity data that might shed light upon how zoonotic disease transmission was occurring. All but one household reported a male as the head of the household. It was observed that this household appeared to have no adult male. Age of the head of the household was on average 41 years old. A similar study in Tov aimag found an older mean at 47 years old for heads of the household (Zhen et al. 2010). It is unknown if this observed difference was due to our focus upon sampling horse and camel herders, the aimags, or the 10-year sampling date difference, as the study in Tov took place in 2006.

Income was only reported by 14 households. All but two households in Umnugobi reported deriving all their income from livestock. Many reported not knowing their monthly income or that it varied depending on how many animals or animal products they sold. Other indications of wealth such as cell phones or a source of power, primarily solar panels (93.1\%), were owned by all households (Table 2). Furthermore, cell phones have been used effectively worldwide to educate and improve health outcomes on other populations (Krishna et al. 2009), making this a potential platform for future public health outreach.

Education among nomadic families is known to be difficult due to the families' frequent household movements and the labour requirements of herding (Steiner-khamsi and Gerelmaa 2008). Boys from herding families make up an educationally disadvantaged group in Mongolia, as in one report $60 \%$ of school dropouts under the age of 15 were boys from herding families (Steiner-khamsi and Gerelmaa 2008). A study conducted in Tov found that $32.4 \%$ of participants had at least a 10th grade education (Zhen et al. 2010), which was higher than our study of $26.7 \%$. However, as Tov is more densely settled than most other aimags (Zhen et al. 2010), access to education may be more consistent. Education is an important factor for health. A study in Europe found that increased education correlated with improved health in men and women over 50 years old. Furthermore, only up to a third of the health effect was derived from differences in tobacco use, drinking, exercise, and body mass index (Brunello et al. 2016).

Increased movement for households has been linked to decreased health in Mongolian nomads, (Mocellin and Foggin 2008) and this may be more extreme in our sample for households who moved further as in their study, a smaller average of $9 \mathrm{~km}$. Extreme weather events, such as drought and $d z u d s$, are known to further increase movement as herders seek grazing and water for livestock (Miao et al. 2016). More than $90 \%$ of the 
households in this study moved at least once during the year. Umnugobi aimag had both the highest percent (13.3\%) who did not move and two families who moved an estimated ten times in a year. Households moved on average $\sim 4$ times a year, traveling 16-34 $\mathrm{km}$ each move (Table 2). Umnugobi households moved the farthest, moving an average of $150 \mathrm{~km}$ each year.

In summary, our study population was comprised primarily of households headed by men with often only an eighth-grade education and access to solar-generated electricity and a mobile phone. More than $90 \%$ of these households moved throughout the year, and all but two derived all their household income from herding. By knowing the characteristics of the households, higher risk individuals in households can be defined by movement and poor education.

\section{Zoonotic risks}

Of all the household livestock, we only examined the number of horses and camels (Table 2). Not all households owned the animals for which they cared. The previously mentioned study in Tov (Zhen et al. 2010) reported fewer horses on average per household at 27 horses compared to the median of 40 in our study. The median number of camels owned per household at 70 was higher than horses. The 3-4 h that households spent with their horses or camels each day included milking and preparation for horse races. Observationally, this number was given for when they were working with the horses or camels and not assumed to be consistent year-round. While making airag (fermented mare's milk), mares are milked five to seven times a day from late June until late summer/fall, depending on geographic region (Bat-Oyun et al. 2015). Bactrian camels were milked on average for 12 months between parturition in one study with a range between 9 and 18 months (Brezovečki et al. 2015). The Umnugobi households in this study reported milking their camels twice a day. Milking requires seasonal, daily interaction with adults and young of both species. Both species are known to be reservoirs for zoonotic diseases, so herders and especially those that milk or drink milk from these animals are at increased risk of zoonoses. In other livestock species, Brucella sp., Mycobacterium sp., Salmonella sp., Listeria monocytogenes, Campylobacter sp., Coxiella burnetii, and Escherichia coli have all been transmitted in unpasteurized milk (John 2006). Little to no research has been focused specifically up mare and camel milk handling in Mongolia, as observationally noted, milk is often drunk unpasteurized, such as with milk tea.

The presence of dogs in more than $90 \%$ of the study households carries transmission risks for zoonoses, including rabies, anthrax, and echinococcosis (Odontsetseg et al. 2009, Odontsetseg et al. 2007, Ito and Budke 2015).
From 2003 to 2005, the most recent years reported by the study of rabies in Mongolia, cases in dogs surpassed cases in livestock (Odontsetseg et al. 2009). Dogs also shed hydatid Echinococcus. Sheep are the primary intermediate host for echinococcosis, but other livestock and humans can also serve as an intermediate host (Jacob and Lorber 2015). This lifecycle makes herder families at high risk for echinococcosis. A review of echinococcosis in Mongolia primarily looked at human caseloads. From 1997 to 2006, community serology studies have found between 2 and $12 \%$ of people positive for Echinococcus granulosus. Studies in domestic dogs have found Echinococcus spp.-positive dogs by both serology (25\%) and necropsy (35\%). Humans are primarily infected by accidental ingestion of food or water contaminated with dog feces (Ito and Budke 2015).

\section{Zoonotic risks: Tobacco use}

Tobacco use is prevalent in Mongolia. Our study found that $42.7 \%$ of heads of the household smoked, which is similar to the $48 \%$ of men nationally surveyed in 2014 (Demaio et al. 2014). In that survey, more urban men smoked, which may account for the lower level seen here. Smoking has been linked with an increase in being serologically positive for zoonotic strains of influenza, both swine and equine (Larson et al. 2015, Coman et al. 2014). This has been explained by increased likelihood of contracting the virus from touching an animal or surface and then one's mouth as well as potentially from a lowered immune system from smoking. In our study, $69.1 \%$ of people used loose tobacco, which may increase the chance of fecal-oral contamination since the tobacco is handled by either rolling it in paper or placing it in a pipe. The 2014 national study found no effect of education on tobacco use, which was also seen in our study (Demaio et al. 2014).

\section{Zoonotic risks: Fuel and water sources}

Fuel source was most commonly wood followed by dried manure. Handling manure for burning as well as using it around cooking areas may increase the risk of enteric pathogen contamination of hands and food. A review of zoonotic pathogens associated with cattle manure found that Salmonella spp., Campylobacter spp., Listeria monocytogenes, Yersinia enterocolitica, Escherichia coli, Cryptosporidium parvum, and Giardia lamblia were all spread in manure. These are known as manure-borne pathogens (Pachepsky et al. 2006, Manyi-Loh et al. 2016). A minimum of three months is needed when the air is more than $0{ }^{\circ} \mathrm{C}$ to properly kill microbes in untreated, dry manure (Manyi-Loh et al. 2016). This is problematic in Mongolia where during much of the year the ambient temperature is below $0{ }^{\circ} \mathrm{C}$. 
Our findings in Uvurkhangai were similar to those found in Tov (Zhen et al. 2010) where $~ 40 \%$ used wood and $\sim 60-70 \%$ used dried manure. Arkhangai used more wood (98.1\%), and Umnugobi households reported burning dried manure for heat 24.3 times more often than the other two aimags. However, Umnugobi is hotter and drier than the other study sites, which may lower the risk of transmission of disease even when more households use dried manure for fuel.

Drinking water was most commonly from a river (60-70\%) in Arkhangai and Uvurkhangai and from an electric well in Umnugobi (70\%). Households in Arkhangai were 4.2 times more likely to use a river as their primary water sources than the other two aimags. Umnugobi was similar to Tov (Zhen et al. 2010) aimag, where water was most commonly from a well $(72.8 \%)$ and then the river (51.5\%). Livestock also used similar water sources as the people. Of the manure-borne pathogens, C. parvum is considered very infectious (Pachepsky et al. 2006) and is relevant to the Mongolian setting. A major source of $C$. parvum from livestock, primarily cattle, is infected drinking water (Hunter and Thompson 2005). Horses are also known to carry C. parvum (Galuppi et al. 2016), and camels have been found to carry other species of Cryptosporidium (Liu et al. 2014). Cryptosporidium sp. was found in rivers in Japan and China (Xiao et al. 2012, Ono et al. 2001), but no test results have been published for Mongolia. Because of their increased use of river water, Arkhangai may be at greater risk for waterborne pathogens than the other two aimags.

In 2015, the United Nations reported that $59.2 \%$ of Mongolian rural populations used improved drinking water sources; this included covered wells (United Nations Data 2017). This was not true in our study as more than $50 \%$ used the river as a water source. However, our study participants were not randomly chosen and were limited by type of livestock owned. In our study, $48.8 \%$ had access to wells, but it is unknown how many of these wells would be considered improved. Thus, focus should be upon lowering risks for transmission of manure-borne pathogens in all rural water sources.

\section{Limitations}

All responses were self-reported leading to possible misclassification. Specifically, some participants appeared to be hesitant or unable to give an exact number of the livestock or other domestic animals associated with the household. Some people counted those only belonging to the one household, and others claimed an amount for the extended family. This discrepancy was especially true when counting the number of dogs owned by the household compared to the number observed at the household residence. In future studies, it would be suggested to ask both numbers owned and numbers on premises.
Also, as all households were not chosen randomly, external validity is a concern. Since our households were chosen by the local veterinarian, it would be expected that households that were missed were more isolated and zoonotic risks for these families could potentially be higher due to a lack of sanitation and water or more livestock diseases from reduced access to veterinary care.

\section{Conclusions}

In this survey, Mongolian herder households had numerous potential risk factors for zoonotic pathogen infection. This was often due to their close contact with livestock, especially horses and camels, or their risky hygienic practices. All five of the most prevalent zoonotic diseases found in Mongolia have been linked to exposure with horses and three with exposure to camels. Of these, anthrax, rabies, and brucellosis have each been found in both camels and horses in Mongolia. Often, these pathogen transmission risks involve direct contact with camels or horses through activities such as milking. Other risks for infection include handling manure that is used for fuel and/or ingestion of contaminated water. This study also highlighted the need for more research to examine the prevalence of these pathogens within the Mongolian pastoral context. Research on these pathogens has been primarily focused on more intensive or stationary livestock management systems. Furthermore, very little research has been performed on milk handling and consumption for horses and camels. Cell phones were present in all herder households, providing a potential platform for the spread of public health information even in rural areas.

\section{Additional file}

\section{Additional file 1: Household Survey. (DOCX 55 kb)}

\section{Acknowledgements}

This study was made possible due to the support provided by the Institute of Veterinary Medicine, the National Centre for Zoonotic Diseases, and the Mongolian Academy of Medical Sciences in Mongolia. We thank Dr. P. Nymadawa and Damiran "EA" Enkhamgalan of the Mongolian Academy of Medical Sciences; Nyamdorj Tsogbadrakh and Damdindorj Tserennorov of the National Centre for Zoonotic Diseases; and Dr. Batsukh Zayat DVM, PhD, ScD, of the Institute of Veterinary Medicine for their leadership and guidance. We also thank professionals from the National Center for Zoonotic Disease branches in Arkhangai, Uvurkhangai, and Umnugobi as well as the aimag and local veterinarians.

\section{Funding}

Funding for this work was provided by the USA National Institutes of Health, Fogarty International Center grant, D43TW009373, "One Health Innovation Fellowships for Zoonotic Disease Research in Mongolia".

\section{Authors' contributions}

All authors have reviewed and approved of the manuscript's submission. Each author has contributed to this work. AS drafted the manuscript, performed the fieldwork, and revised the manuscript. UD and MC designed the survey, 
performed the fieldwork, and revised the manuscript. GG and BG helped in designing the survey, interpreted the data, and revised the manuscript. The manuscript has not been previously published nor is it being considered for publication elsewhere.

\section{Ethics approval and consent to participate}

This project received ethical approval from Duke University's Institutional Review Board (IRB, \#Pro00065336), as well as full approval from the Mongolian Monitoring Committee of Medical Ethics - Ministry of Health. All participants signed a consent form explaining what information was being collected and its use. There was no need for consent for publication, as no personal information is being published. Data will not be shared as it contains identifying information.

\section{Competing interests}

The authors declare that they have no competing interests.

\section{Publisher's Note}

Springer Nature remains neutral with regard to jurisdictional claims in published maps and institutional affiliations.

\section{Author details}

${ }^{1}$ Institute of Veterinary Medicine, Ulaanbaatar, Mongolia. ${ }^{2}$ Division of Infectious Diseases, School of Medicine, Duke University, Box 90519, Durham, NC 27710, USA. ${ }^{3}$ Global Health Institute, Duke University, Durham, NC, USA. ${ }^{4}$ Nicholas School of the Environment, Duke University, Durham, NC, USA.

\section{Received: 9 June 2017 Accepted: 11 December 2017}

\section{Published online: 29 January 2018}

\section{References}

Acosta-Jamett, G., S. Cleaveland, A.A. Cunningham, B.M. Bronsvoort, and P.S. Craig. 2010. Echinococcus granulosus infection in humans and livestock in the Coquimbo region, north-central Chile. Veterinary Parasitology 169 (1/2): $102-110$.

Bat-Oyun, T., B. Erdenetsetseg, M. Shinoda, T. Ozaki, and Y. Morinaga. 2015. Who is making airag (fermented mare's milk)? A nationwide survey of traditional food in Mongolia. Nomadic Peoples 19 (1): 7-29.

Brezovečki, A., M. Čagali, Z.F. Dermit, N. Mikulec, D.B. Ljoljić, and N. Antunac. 2015. Camel milk and milk products. Mljekarstvo 65 (2): 81-90.

Brunello, G., M. Fort, N. Schneeweis, and R. Winter-Ebmer. 2016. The causal effect of education on health: What is the role of health behaviors? Health Economics 25 (3): 314-336.

Coman, A., D.N. Maftei, W.S. Krueger, G.L. Heil, R.M. Chereches, E. Sirlincan, P. Bria, C. Dragnea, I. Kasler, M.A. Valentine, and G.C. Gray. 2014. A prospective study of Romanian agriculture workers for zoonotic influenza infections. PLoS One 9 (5): e98248.

Demaio, A.R., J. Nehme, D. Otgontuya, D.W. Meyrowitsch, and P. Enkhtuya. 2014 Tobacco smoking in Mongolia: Findings of a national knowledge, attitudes and practices study. BMC Public Health 14 (1): 213-213.

Eldevochir, E. 2016. Livestock statistics in Mongolia. Edited by National Statistical Office of Mongolia.

Faye, B. 2015. Role, distribution and perspective of camel breeding in the third millennium economies. Emirates Journal of Food and Agriculture 27 (4): 318.

Galuppi, R., S. Piva, C. Castagnetti, G. Sarli, E. lacono, M.L. Fioravanti, and M. Caffara. 2016. Cryptosporidium parvum: From foal to veterinary students. Veterinary Parasitology 219: 53-56.

Hunter, P.R., and R.C.A. Thompson. 2005. The zoonotic transmission of Giardia and Cryptosporidium. International Journal for Parasitology 35 (11-12): 1181-1190.

Ito, A., and C.M. Budke. 2015. The present situation of echinococcoses in Mongolia. Journal of Helminthology 89 (6): 680.

Jacob, J., and B. Lorber. 2015. Diseases transmitted by man's best friend: The dog. Microbiol Spectr 3 (4): IOL-0002-2015.

John, M.L. 2006. Milk of nonhuman origin and infectious diseases in humans. Clinical Infectious Diseases 43 (5): 610-615.

Krishna, S., S.A. Boren, and E.A. Balas. 2009. Healthcare via cell phones: A systematic review. Telemedicine Journal and e-Health: The Official Journal of the American Telemedicine Association 15 (3): 231-240.

Larson, K.R., G.L. Heil, T.M. Chambers, A. Capuano, S.K. White, and G.C. Gray. 2015. Serological evidence of equine influenza infections among persons with horse exposure, lowa. Journal of Clinical Virology 67: 78-83.
Liu, X., X. Zhou, Z. Zhong, J. Deng, W. Chen, S. Cao, H. Fu, Z. Zuo, Y. Hu, and G. Peng. 2014. Multilocus genotype and subtype analysis of Cryptosporidium andersoni derived from a Bactrian camel (Camelus bactrianus) in China. Parasitology Research 113 (6): 2129-2136.

Manyi-Loh, C.E., S.N. Mamphweli, E.L. Meyer, G. Makaka, M. Simon, and A.I. Okoh. 2016. An overview of the control of bacterial pathogens in cattle manure. International Journal of Environmental Research and Public Health 13 (9): 843.

Marin, A. 2010. Riders under storms: Contributions of nomadic herders' observations to analysing climate change in Mongolia. Global Environmental Change 20 (1): 162-176.

McFadden, A.M.J., P. Muellner, Z. Baljinnyam, D. Vink, and N. Wilson. 2016. Use of multicriteria risk ranking of zoonotic diseases in a developing country: Case study of Mongolia. Zoonoses and Public Health 63 (2): 138-151.

Merini, L.P., A.T. Cormelato, C.A. de Castro Beck, P. Garbade, F.U. Bueno, P.M. Ocampos Pedroso, and S. Carnesella. 2010. Equine rabies in the city of Porto Alegre - RS, Brazil. Acta Scientiae Veterinariae 38 (2): 213-216.

Miao, L., R. Fraser, Z. Sun, D. Sneath, B. He, and X. Cui. 2016. Climate impact on vegetation and animal husbandry on the Mongolian plateau: A comparative analysis. Natural Hazards 80 (2): 727-739.

Mocellin, J., and P. Foggin. 2008. Health status and geographic mobility among semi-nomadic pastoralists in Mongolia. Health \& Place 14 (2): 228-242.

Mongolian National Chamber of Commerce and Industry. 2017. Internal branches.http://www.mongolchamber.mn/en/. Accessed 26 Apr 2017.

Moraes Filho, J., M.C. Horta, R.D.C. Pacheco, M.M. Maeda, A. Galano, M.L. de Oliveira, L.E.O. Yai, and M.B. Labruna. 2009. Detection of antibodies against Rickettsia rickettsii in equines of the Zoonosis Control Center of São Paulo Municipality (CCZ/SP). / Pesquisa de anticorpos anti-Rickettsia rickettsii em eqüinos do Centro de Controle de Zoonoses do município de São Paulo (CCZ/SP). Brazilian Journal of Veterinary Research and Animal Science 46 (2): 85-91.

National Statistics Office. 2015. Summary of livestock for 2015. http://www.1212. mn/tables.aspx?TBL_ID=DT_NSO_1001_021V1. Accessed 26 Apr 2017.

Odontsetseg, N., T. Sh, Z. Adiyasuren, D. Uuganbayar, and A.S. Mweene. 2007. Anthrax in animals and humans in Mongolia. Revue scientifique et technique (International Office of Epizootics) 26 (3): 701.

Odontsetseg, N., D. Uuganbayar, S. Tserendorj, and Z. Adiyasuren. 2009. Animal and human rabies in Mongolia. Revue Scientifique Et Technique-Office International Des Epizooties 28 (3): 995-1003.

Ono, K. H. Tsuji, S.K. Rai, A. Yamamoto, K. Masuda, T. Endo, H. Hotta, T. Kawamura, and S. Uga. 2001. Contamination of river water by Cryptosporidium parvum oocysts in western Japan. Applied and Environmental Microbiology 67 (9): 3832-3836.

Otani, S., K. Onishi, Y. Kurozawa, Y. Kurosaki, T. Bat-Oyun, M. Shinoda, and H. Mu. 2016. Assessment of the effects of severe winter disasters (Dzud) on public health in Mongolia on the basis of loss of livestock. Disaster Medicine and Public Health Preparedness 10 (4): 549-552.

Pachepsky, Y.A., A.M. Sadeghi, S.A. Bradford, D.R. Shelton, A.K. Guber, and T. Dao. 2006. Transport and fate of manure-borne pathogens: Modeling perspective. Agricultural Water Management 86 (1): 81-92.

Rushton, J.O., S. Lecollinet, Z. Hubálek, P. Svobodová, H. Lussy, and N. Nowotny. 2013. Tick-borne encephalitis virus in horses, Austria, 2011. Emerging Infectious Diseases 19 (4): 635.

Santos, R.F., G.C.P. Silva, N.A. Assis, and L.A. Mathias. 2016. Brucella spp. in equines slaughtered in the south region of Brazil. Arquivo Brasileiro de Medicina Veterinária e Zootecnia 68 (4): 853-857.

Sharma, K, and O. Davaakhuu. 2015. Trade policymaking in a resource-rich landlocked country: The WTO review of Mongolia. The World Economy 38 (9): 1350-1367.

Steiner-khamsi, G., and A. Gerelmaa. 2008. Quality and equity in the Mongolian education sector. Prospects 38 (3): 409-414.

Suttie, J.M. 2005. Grasslands of the world. Edited by Caterina Batello, Stephen G. Reynolds and J. M. Suttie. Vol. 34, Plant production and protection. Rome: Food and Agricultural Organization of the United Nations.

Tahamtan, Y., M.M. Namavari, G. Mohammadi, and G.M. Jula. 2010. Prevalence of brucellosis in horse north-east of Iran. Journal of Equine Veterinary Science 30 (7): 376-378.

Turner, A.J., J.W. Galvin, R.J. Rubira, and G.T. Miller. 1999. Anthrax explodes in an Australian summer. Journal of Applied Microbiology 87 (2): 196-199.

United Nations Data. 2017. Mongolia. http://data.un.org/CountryProfile. aspx? crname=Mongolia.

Xiao, S., W. An, Z. Chen, D. Zhang, J. Yu, and M. Yang. 2012. Occurrences and genotypes of Cryptosporidium oocysts in river network of southern-eastern China. Parasitology Research 110 (5): 1701-1709. 
Zhen, L., B. Ochirbat, Y. Lv, Y.J. Wei, X.L. Liu, J.Q. Chen, Z.J. Yao, and F. Li. 2010. Comparing patterns of ecosystem service consumption and perceptions of range management between ethnic herders in Inner Mongolia and Mongolia. Environmental Research Letters 5 (1): 015001.

Zolzaya, B., T. Selenge, T. Narangarav, D. Gantsetseg, D. Erdenechimeg, J. Zinsstag, and E. Schelling. 2014. Representative seroprevalences of human and livestock brucellosis in two Mongolian provinces. EcoHealth 11 (3): 356-371.

\section{Submit your manuscript to a SpringerOpen ${ }^{\circ}$ journal and benefit from:}

- Convenient online submission

- Rigorous peer review

- Open access: articles freely available online

- High visibility within the field

- Retaining the copyright to your article

Submit your next manuscript at $\boldsymbol{\sim}$ springeropen.com 